\title{
Experimental Behavior of Composite Infilled \& Encased Column by using MSAND, Metakaolin \& Recron Fibre
}

\author{
M.R.Ganesamoorthy, S.Arivalagan
}

\begin{abstract}
In this analysis, take a look at on compressive strength of composite infilled and encased columns were done. Compressive strength of hollow, tubular and encased typical section in addition as Msand, silcafume, metakaolin \& recorn fiber concrete-filled tubes were decided. Cross-section, compressive strength, and mode of failure of the column to be explored. The circular section and square section were selected for this research. The association between the load, and the later displacement at the mid-tallness, base, and top of the sections inside the bearing of each the durable and powerless axes, and furthermore the connections of burden versus complete the process of shortening for each example was reliably recorded. It completely was discovered that the load carrying limit differs with importance to the cross-section of the specimen, compressive strength of the infill material. The investigation is carried out for the water-cement ratio of $0.5 \%$ for in composite column of size 150 $\times 150 \times 1800 \mathrm{~mm}$ and diameter of $1800 \mathrm{~mm}$ of square and circular section. Then the specimens are to be tested on $7^{\text {th }}$ day, $14^{\text {th }}$ day and $28^{\text {th }}$ day. The circular specimens having higher load-carrying capacity than square specimens. Msand, metakaolin and recron fiber waterproof agent concrete infilled in and encased steel tubes show $5 \%$ to $15 \%$ more strength than typical control concrete-filled steel tubes.
\end{abstract}

Keywords: Metakaolin, Msand, slicafume, Recronfibre, steel, infill, Encased concrete, CFST columns

\section{INTRODUCTION}

Steel and concrete composite columns were utilized for many years for its wider benefits of fire protection. At present the use of steel composite concrete is kept on increasing in much structural application and also, it's used in offshore structures, bridges, and columns in seismic zones for its natural ductile property enhance the compression strength of concrete. Its advantages incorporate Higher solidarity to weight extent connection and preferred inflexibility over the concrete column. Higher versatility and strength for opposing reversal load. Higher load-resisting ability exposed to the composite activity among steel and cement. Sparing in material and development time. Steel tubes likewise are utilized as perpetual formwork. In empty steel cylindrical areas, that are prevalently used in elevated structures, each internal and outward clasping is found. Though for the solid filled steel tube, exclusively outward clasping is found inside the cylinder, and in this manner the inward concrete flops in an exceptionally a great deal of pliable elegance.

Revised Manuscript Received on November 19, 2019

M.R.Ganesamoorthy, Research scholar, St. Peters University, Chennai, India, Tamil Nadu, India.

S.Arivalagan, Professor \& Head, Dr. M.G.R University. (Educational and Research Institute) Chennai-95, Tamil Nadu, India.
Two forms of composite columns, those with steel section cased in concrete and those with steel section in-filled with concrete are commonly utilized in buildings concrete-filled steel hollow columns are used for earthquake-resistant structures, bridge piers subjected to impact from traffic, columns to support storage tanks, decks of railways, columns in high-rise buildings and as piles. Concrete-filled steel tubes want more fire-retardant insulation if fire protection of the structure is vital. With the increased use of composite columns, a great deal of theoretical and experimental work has proceeded. This paper presents the state of art data on steel-concrete composite columns alongside experimental studies. An overview of experimental reportable in literature is given in associate passing tabular kind. The discussion includes the behavior of slender composite columns. The employment of high strength concrete in composite columns is shortly created public. An in-depth discussion on the results of local buckling, bond strength, confinement of concrete, and secondary stresses on composite columns are given.

This paper deals with the behavior of the stiffened concrete-filled steel composite columns subjected to axial loading. The most common parameters are order of steel tubes, the dimension of bar stiffeners is eight-millimeter, the wall thickness of steel is two millimeters, concrete compressive strengths from twenty to forty $\mathrm{Mpa}$, and steel yield stresses from two fifty to five hundred Mpa. The final load carrying capacity and ductile behavior completely experimented. The additional result of various numbers and spacing of the bar stiffeners and concrete compressive and yield strength on the maximum load carrying capacity of the columns are evaluated. Failure modes of the columns are examined. Based on the results from various testing the maximum load carrying capacity of the columns is identified.

If the composite infilled columns are often used for structural and non-structural applications, it had not solely been helpful towards the surrounding however even be advantageous for low-income families as this concrete is often used for the development of inexpensive homes and reduced construction time. So that this work shows the results of experimental findings on composite column using cement, Msand, metakaolin, and recron fiber with water proofer additionally used for increasing the bonding strength and decreasing the corrosion of steel.

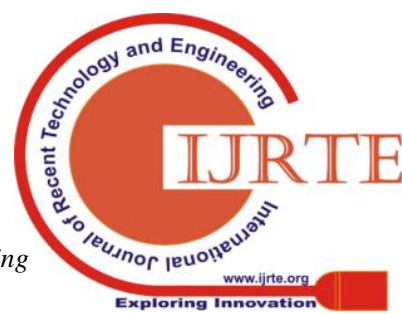


Experimental Behavior of Composite Infilled \& Encased Column by using MSAND, Metakaolin \& Recron Fibre

\section{TEST SPECIMENS AND MATERIAL PROPERTIES}

Table 1 Sectional properties of specimens

\begin{tabular}{|c|c|c|c|c|}
\hline LBSEL & 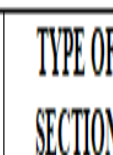 & 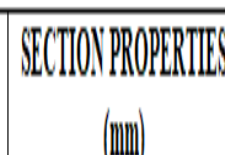 & 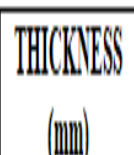 & $\mathbb{H}$ \\
\hline $\mathrm{HWOWH}$ & BillOOI & 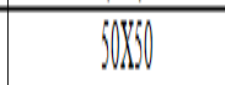 & ! & 1900 \\
\hline $\mathrm{MWl} / \mathrm{N}$ & 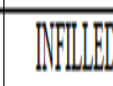 & $\sqrt{1 / 20}$ & 1 & 1800 \\
\hline COPG & 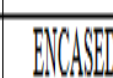 & 190710 & $\frac{1}{1}$ & 190 \\
\hline
\end{tabular}

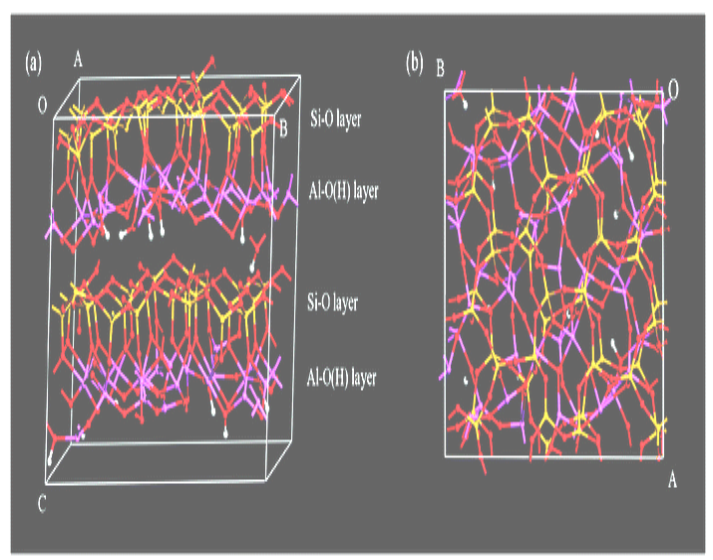

Fig. 1. Structure of natural Metakaolin

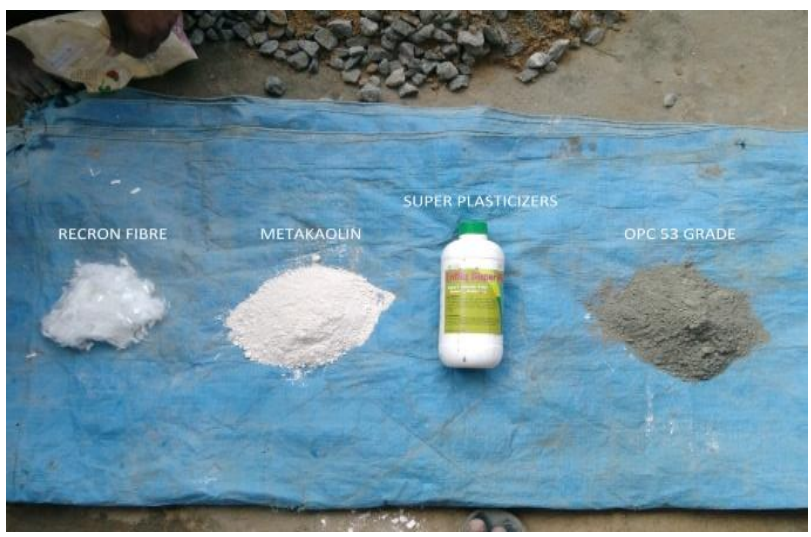

Fig.2 Materials used for concrete

Table 2 Chemical properties of material

\begin{tabular}{|c|c|c|}
\hline Chemical composition (\%) and physical properties & Metakaolin & Cement \\
\hline $\mathrm{Ca}_{\mathrm{a} 0}$ & $<0.20$ & 62.1 \\
\hline $\mathrm{SiO}_{2}$ & $51-53$ & 18.8 \\
\hline $\mathrm{Al203}$ & $42-44$ & 3.9 \\
\hline $\mathrm{Fe} 203$ & $<2.20$ & 2.8 \\
\hline $\mathrm{MgO}$ & $<0.10$ & 2.6 \\
\hline $\mathrm{Na20}$ & $<0.05$ & 0.20 \\
\hline $\mathrm{K} 20$ & $<0.40$ & 1.06 \\
\hline
\end{tabular}

2.1 Recron Fibre:
The most important recron $3 \mathrm{~s}$ fiber was used as a secondary reinforcement material. It is used to arrest shrinkage cracks and also it is good water resistance to water penetration, impact, and abrasion. If it is used to make concrete, it is more consistent and in addition improves the compressive strength, plasticity, and flexural strength together with rising the ability to absorb more energy. The employment of uniformly unfold recron $3 \mathrm{~s}$ fibers reduces segregation and injury, resulting in more of unvaried combines. It ends up the higher strength and reduced consistency that improves the durability. "Table 3" which shows the properties in physical form of recron $3 \mathrm{~s}$ fiber.

Table 3. Properties in the physical form of Recron $3 \mathrm{~s}$ Fiber

\begin{tabular}{|c|c|}
\hline Type & Polyester - CT2012 \\
\hline Shape & Triangle. \\
\hline Length & $6 \mathrm{~mm}$ \\
\hline Performance & Outstanding \\
\hline Resistant for acid & Outstanding \\
\hline Degree at melting stage & 250 degree Celsius \\
\hline
\end{tabular}

\subsection{Super Plasticizers:}

Superplasticizers, additionally mentioned as good water reducers and chemical admixtures are used for the good-split up particle is required. The polymers are utilized as good-split up to evade particle segregation (that is fine sand, coarse and gravel) and to spice up the flow features of suspensions like the application of concrete. The mortar or concrete which is used in addition to this process reduces the water-cement ratio and it touches the workability of the mixture and permits the mixing of high-performance concrete and self-consolidation concrete. This factor improves the hardening state of fresh concrete. the strength of concrete depends upon the water-cement ratio. If the water cement ration reduces automatically the strength of concrete increase. For this reason full understanding is required for adding super plasticizer.

\section{COMPOSITE COLUMN MIX DESIGN OF M20 AND M40 GRADE CONCRETE}


International Journal of Recent Technology and Engineering (IJRTE) ISSN: 2277-3878, Volume-8 Issue-4, November 2019

\begin{tabular}{|c|c|c|c|}
\hline \multirow{2}{*}{ Types of Concrete } & \multirow{2}{*}{ Various material used } & \multicolumn{2}{|c|}{ Weights are in $(\mathrm{Kg})$} \\
\hline & & M20 Grade & M40 Grade \\
\hline \multirow{5}{*}{$\begin{array}{l}\text { Conventional } \\
\text { Concrete }\end{array}$} & Volume of concrete & $31.80 \times 10^{6} \mathrm{~mm}^{3}$ & $31.80 \times 10^{6} \mathrm{~mm}^{3}$ \\
\hline & Volume of cement & $13 \mathrm{Kg}$ & $13 \mathrm{Kg}$ \\
\hline & Volume of water & 6.5 lit & 6.5 lit \\
\hline & The volume of fine aggregate & $20 \mathrm{~kg}$ & $13 \mathrm{~kg}$ \\
\hline & The volume of coarse aggregate & $40 \mathrm{Kg}$ & $30 \mathrm{Kg}$ \\
\hline \multirow{8}{*}{$\begin{array}{l}\text { MRC. } 1 \& \text { MRC. } 2 \\
\text { Concrete }\end{array}$} & Volume of concrete & $31.8 \times 10^{6} \mathrm{~mm}^{3}$ & $31.8 \times 10^{6} \mathrm{~mm}^{3}$ \\
\hline & Volume of cement & $13 \mathrm{Kg}$ & $13 \mathrm{Kg}$ \\
\hline & Replace $10 \%$ metakaolin & $1.30 \mathrm{Kg}$ & $1.30 \mathrm{Kg}$ \\
\hline & volume of silica fume & $1.30 \mathrm{~kg}$ & $1.30 \mathrm{~kg}$ \\
\hline & Volume of water & 6.5 lit & 6.5 lit \\
\hline & Volume of fine aggregate & $20 \mathrm{~kg}$ & $13 \mathrm{~kg}$ \\
\hline & Volume of coarse aggregate & $40 \mathrm{Kg}$ & $30 \mathrm{Kg}$ \\
\hline & $3 \%$ Recron fibre & $0.39 \mathrm{Kg}$ & $0.39 \mathrm{Kg}$ \\
\hline \multirow{8}{*}{$\begin{array}{c}\text { MRC11\&MRC22 } \\
\text { Concrete }\end{array}$} & Volume of concrete & $31.8 \times 10^{6} \mathrm{~mm}^{3}$ & $31.8 \times 10^{6} \mathrm{~mm}^{3}$ \\
\hline & Volume of cement & $13 \mathrm{Kg}$ & $13 \mathrm{Kg}$ \\
\hline & Replace $15 \%$ metakaolin & $1.95 \mathrm{Kg}$ & $1.95 \mathrm{Kg}$ \\
\hline & volume of silica fume & $1.95 \mathrm{~kg}$ & $1.95 \mathrm{~kg}$ \\
\hline & Volume of water6 & 6.5 lit & .6 .5 lit \\
\hline & Volume of fine aggregate & $20 \mathrm{~kg}$ & $13 \mathrm{~kg}$ \\
\hline & Volume of coarse aggregate & $40 \mathrm{Kg}$ & $30 \mathrm{Kg}$ \\
\hline & $3 \%$ Recron fibre & $0.39 \mathrm{Kg}$ & $0.39 \mathrm{Kg}$ \\
\hline
\end{tabular}

\section{INSTRUMENTATION.}

The displacement gauges called deflectometer were utilized to measure the extension and contraction on the measuring axis. The mechanical strain gauge was the instrument used to measure the unit deformation which is elongation and contraction same is placed in longitudinal direction. The readings are taken manually. The loading frame testing machines of capability seven hundred kilo newton and thousand-kilo newton's were used to find the required data from the test. Totally 3 strain gauges were used and the same place in two different sides and mid- heights of the sample vertical shown in figure 5. The axial contraction was used to measure using mechanical strain gauge which is placed at the center and 2 deflectometer are placed at bottom and top for measuring the deflection due to applied loading.

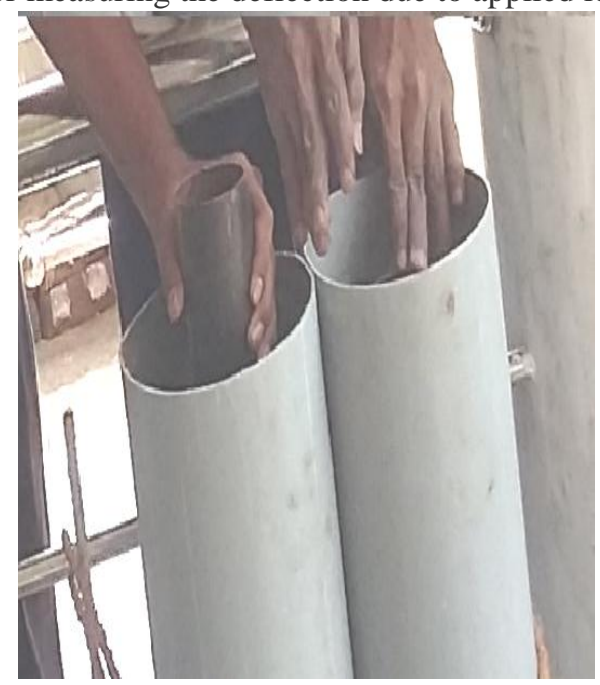

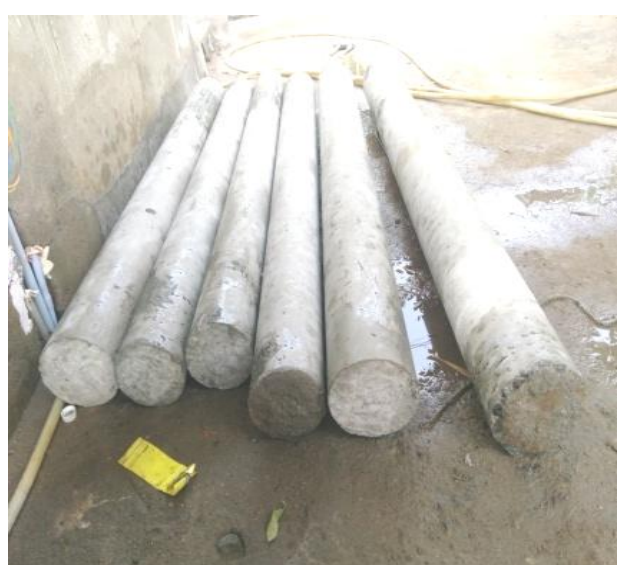

Fig.3, 4. Specimens Moldings and Deshuttering stages

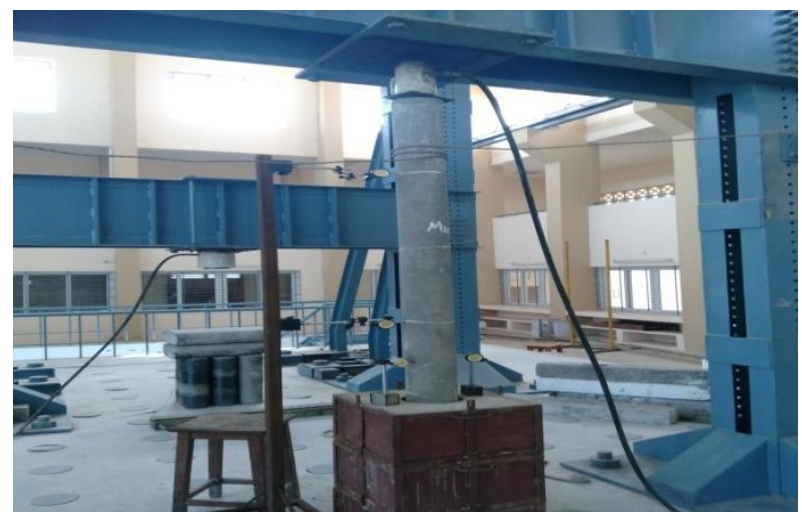

Fig.5. Specimen set up in the loading frame

Published By:

Blue Eyes Intelligence Engineering

\& Sciences Publication 


\section{Experimental Behavior of Composite Infilled \& Encased Column by using MSAND, Metakaolin \& Recron Fibre}

The compression test was performed based on the assumption of axial compression. In this test potential shear and bending values produced by loading and the deformation throughout the test, the process was neglected. The bottom and ends are assumed as hinged support and only axial force transition alone permitted.

\section{RESULTS AND DISCUSSION}

\subsection{Workability}

The commonly adopted workability test of a slump and compaction factor test was performed. workability of both conventional and CFSTC (MRC) concrete has been analyzed and presented in "Table 3".

Table 3. Workability of CC and MRC

\begin{tabular}{|l|c|}
\hline Type of concrete & Slump (mm) \\
\hline Conventional concrete & 110 \\
\hline Metakaolin\&Recronfibre & 80 \\
\hline
\end{tabular}

\subsection{Concrete Properties}

The fresh concrete density for conventional concrete in a composite column was $3164 \mathrm{~kg} / \mathrm{m}^{3}$.and for MRC 1 was $3031 \mathrm{~kg} / \mathrm{m}^{3}$ and for MRC 2 was $2981 \mathrm{~kg} / \mathrm{m}^{3}$ and these readings are shown in "Table 4 "

Table 4. The Density of CC and MRC

\begin{tabular}{|c|c|}
\hline TYPE OF CONCRETE & $\begin{array}{l}\text { FRESH CONCRETE } \\
\left.\text { DENSITY (kg/m } \mathbf{m}^{\mathbf{3}}\right)\end{array}$ \\
\hline Conventional concrete & 2950 \\
\hline $\begin{array}{c}\text { Metakaolin\&Recronfibre 1 } \\
\mathbf{M}_{20}\end{array}$ & 3254 \\
\hline $\begin{array}{c}\text { Metakaolin\&Recronfibre 2 } \\
\mathbf{M}_{40}\end{array}$ & 3446 \\
\hline $\begin{array}{c}\text { Metakaolin\&Recronfibre 11 } \\
\mathbf{M}_{20}\end{array}$ & 3350 \\
\hline $\begin{array}{c}\text { Metakaolin\&Recronfibre } \\
22 \mathrm{M}_{40}\end{array}$ & 3680 \\
\hline
\end{tabular}

\subsection{The Compressive Strength Of Cube Specimen}

The average compression strength of metakaolin, sliocafume \& recronfibre concrete1 for unconfinement is $33.80 \mathrm{~N} / \mathrm{mm}^{2}$. The average compression strength of metakaolin, slicafume $\&$ recronfibre concrete 2 for unconfinement is $37.50 \mathrm{~N} / \mathrm{mm}^{2}$. The average compression strength of conventional concrete for un confinement is 29.33 $\mathrm{N} / \mathrm{mm}^{2}$ at 28 days. Table 5 and Fig 6 show the compressive strength of conventional concrete and MRC $1 \&$ MRC 2.
Table 5. properties of CC, MRC.1, and MRC.2 in cube specimen of $\mathrm{M}_{20}$ grade concrete

\begin{tabular}{|c|c|c|c|c|c|c|c|c|c|}
\hline \multirow[t]{2}{*}{ Sppecimen } & \multicolumn{3}{|c|}{ 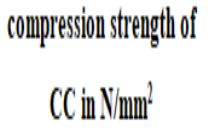 } & \multicolumn{3}{|c|}{ 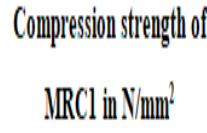 } & \multicolumn{3}{|c|}{$\begin{array}{l}\text { Compression strength of } \\
\text { IRRCY in. } V / \mathrm{mml}^{2}\end{array}$} \\
\hline & 7 days & 14days & 28days & 7days & 14 days & 28days & 7days & 14 days & 28day \\
\hline 1 & 17.30 & 24.70 & 30.00 & 18.56 & 25.20 & 33.60 & 19.68 & 30.20 & 37.75 \\
\hline 2 & 6.75 & 23.65 & 31.66 & 19.20 & 27.85 & 34.90 & 20.85 & 29.35 & 36.85 \\
\hline 3 & 18.40 & 25.90 & 27.80 & 17.75 & 28.55 & 32.89 & 18.85 & 28.65 & 37.90 \\
\hline Arg & 17,65 & 24.75 & 29,83 & 18.50 & 27.20 & 33,80 & 19,80 & 29,50 & 37,50 \\
\hline
\end{tabular}

Fig 6. Properties of $\mathrm{CC}, \mathrm{MRC1}$ and $\mathrm{MRC} 2$ in cube specimen of $\mathrm{M}_{20}$

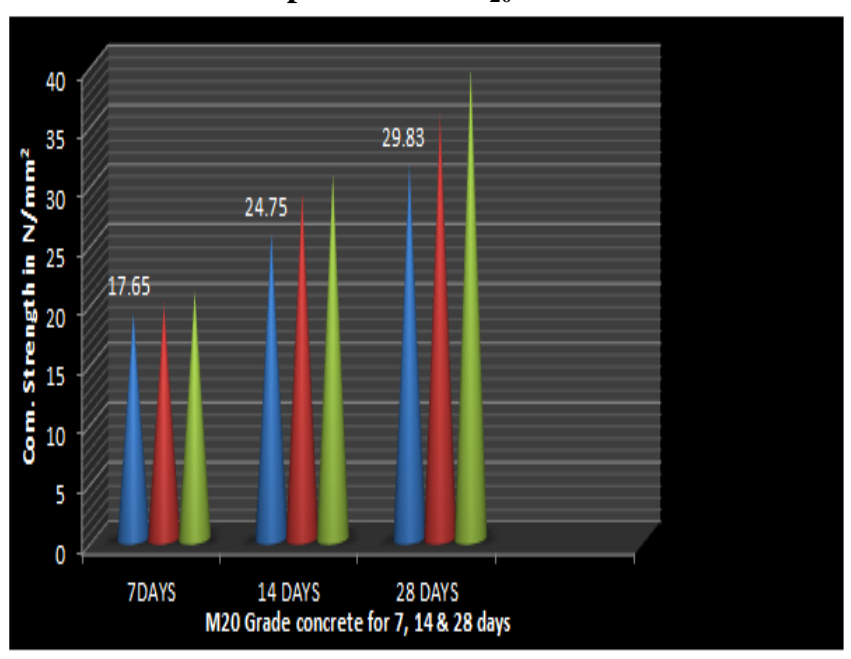

Table 6. Properties of CC, MRC.11 and MRC.22 for cube specimen of $\mathrm{M}_{40}$ grade concrete

\begin{tabular}{|c|c|c|c|c|c|c|c|c|c|}
\hline \multirow[t]{2}{*}{ Speciment } & \multicolumn{3}{|c|}{$\begin{array}{l}\text { Compression strength of } \\
\text { CC in } \mathrm{V} / \mathrm{mm}^{l}\end{array}$} & \multicolumn{3}{|c|}{$\begin{array}{l}\text { Compression strength of } \\
\text { IIRC.11 in } \mathrm{N} / \mathrm{mm}^{2}\end{array}$} & \multicolumn{3}{|c|}{$\begin{array}{l}\text { Compression strength of } \\
\text { IRRC.2L in } . / \mathrm{mm}^{2}\end{array}$} \\
\hline & 7 days & 14day & 28days & 7days & 14 days & $\begin{array}{c}28 d a y \\
s\end{array}$ & 7days & $\begin{array}{l}14 \\
\text { days }\end{array}$ & 28days \\
\hline 1 & 23.45 & 29.68 & 43.55 & 30.35 & 41.50 & 55.50 & 37.50 & 47.50 & 62.55 \\
\hline 2 & 24.75 & 35.75 & 41.65 & 29.55 & 42.25 & 52.56 & 34.50 & 46.25 & 65.50 \\
\hline 3 & 26.20 & 32.90 & 42.15 & 32.25 & 43.56 & 49.70 & 36.65 & 48.50 & 59.60 \\
\hline Avg & 24.80 & 32.78 & 42.45 & 30.72 & 42.44 & 52.59 & 36.21 & 47.42 & 62.55 \\
\hline
\end{tabular}


Table 7. CC $\mathrm{M}_{20}$ CONCRETE COLUMN CIRCULAR SECTION FOR 28 DAYS

\begin{tabular}{|c|c|c|c|c|c|c|c|c|c|}
\hline \multirow[t]{2}{*}{$\mathrm{LOAD}(\mathrm{KI})$} & \multicolumn{3}{|c|}{ TOP } & \multicolumn{3}{|c|}{ IIIDDLE } & \multicolumn{3}{|c|}{ BOTTO.II } \\
\hline & Inmel' & Outtel' & F.R & Inmel' & Outen' & ER & Inmel' & Outtel' & ER \\
\hline 50 & 0 & 45 & 0.45 & 0 & 25 & 0.25 & 0 & 20 & 0.2 \\
\hline 100 & 0 & 95 & 0.95 & 0 & 50 & 0.5 & 2 & 45 & 2.45 \\
\hline 150 & 1 & 20 & 1.2 & 1 & 90 & 1.9 & 2 & 70 & 2.7 \\
\hline
\end{tabular}

Table 8. MRC .1. $M_{20}$ CONCRETE COLUMN CIRCULAR SECTION FOR 28 DAYS

\begin{tabular}{|c|c|c|c|c|c|c|c|c|c|}
\hline \multirow{2}{*}{ LOAD (KI) } & \multicolumn{3}{|c|}{ IOP } & \multicolumn{3}{c|}{ IIIDDLE } & \multicolumn{3}{c|}{ BOTTO.I } \\
\cline { 2 - 11 } & Inner' & Outer & F.R & Immer' & Outer & F.R & Inmer & Outer & F.R \\
\hline 50 & 0 & 20 & 0.2 & 0 & 200 & 2 & 0 & 70 & 0.7 \\
\hline 100 & 0 & 60 & 0.6 & 0 & 10 & 0.1 & 1 & 20 & 1.2 \\
\hline 150 & 0 & 95 & 0.95 & 0 & 40 & 0.4 & 1 & 40 & 1.4 \\
\hline 200 & 1 & 20 & 1.2 & 1 & 80 & 1.8 & 2 & 75 & 2.75 \\
\hline 250 & 1 & 75 & 1.75 & 2 & 00 & 2.0 & 2 & 95 & 2.95 \\
\hline
\end{tabular}

Table 9. MRC2, $M_{20}$ CONCRETE COLUMN CIRCULAR SECTION FOR 28 DAYS

\begin{tabular}{|c|c|c|c|c|c|c|c|c|c|}
\hline \multirow[t]{2}{*}{$\begin{array}{l}\mathrm{LOAD} \\
(\mathrm{KN})\end{array}$} & \multicolumn{3}{|c|}{$\begin{array}{c}\text { TOP } \\
\text { Deflection in mm }\end{array}$} & \multicolumn{3}{|c|}{$\begin{array}{c}\text { IIIDDLE } \\
\text { Deflection in mm }\end{array}$} & \multicolumn{3}{|c|}{$\begin{array}{c}\text { BOTTOM } \\
\text { Deflection in mm }\end{array}$} \\
\hline & Innel' & Outer & F.R & Inmer' & Outer' & F.R & Inner' & Outer & FR \\
\hline 50 & 0 & 15 & 0.15 & 0 & 10 & 0.1 & 0 & 70 & 0.7 \\
\hline 100 & 0 & 40 & 0.4 & 0 & 15 & 0.15 & 1 & 90 & 1.9 \\
\hline 150 & 0 & 90 & 0.9 & 0 & 45 & 0.45 & 1 & 25 & 1.25 \\
\hline 200 & 1 & 20 & 1.2 & 1 & 90 & 1.9 & 2 & 70 & 2.7 \\
\hline 250 & 1 & 35 & 1.35 & 1 & 20 & 1.2 & 2 & 10 & 2.10 \\
\hline
\end{tabular}

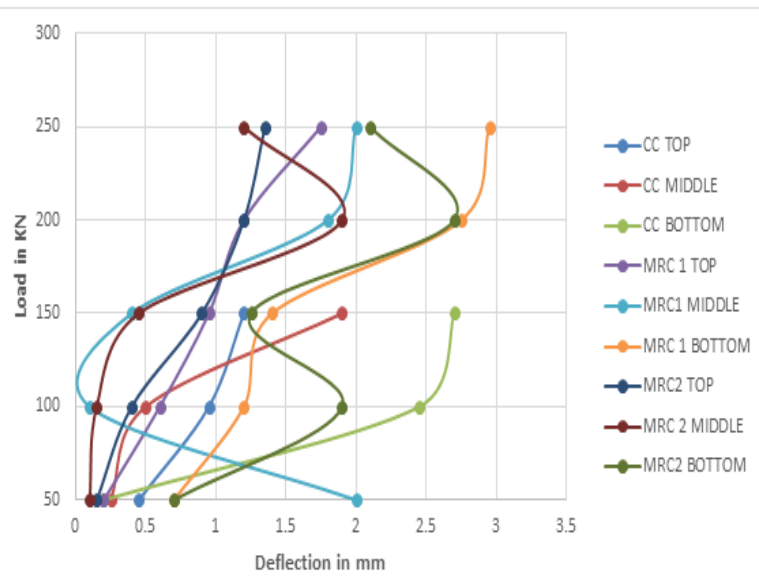

Fig 7. $M_{20}$ Grade concrete Circular section
Table 10. CC 1M 10 $_{0}$ CONCRETE COLUMN

CIRCULAR SECTION FOR 28 DAYS

\begin{tabular}{|c|c|c|c|c|c|c|c|c|}
\hline \multirow[t]{2}{*}{ LOAD $(\mathrm{KI})$} & \multicolumn{3}{|c|}{$\begin{array}{c}\text { TOP } \\
\text { Deflection in m }\end{array}$} & \multicolumn{3}{|c|}{$\begin{array}{c}\text { IIIDDLE } \\
\text { Deflection in ma }\end{array}$} & \multicolumn{2}{|c|}{$\begin{array}{c}\text { BOTTOII } \\
\text { Deflection in mu }\end{array}$} \\
\hline & Inmer & Outter & FR & Imele' & Outer' & $\mathrm{F}, \mathrm{R}$ & Imen' & \begin{tabular}{|l|l|} 
Outerl & F.I
\end{tabular} \\
\hline 50 & 0 & 40 & 0.4 & 0 & 30 & 0.3 & 0 & \begin{tabular}{l|l}
0 & 0
\end{tabular} \\
\hline 100 & 0 & 90 & 0.9 & 1 & 45 & 1.45 & 1 & \begin{tabular}{l|l|}
15 & 1.1 \\
\end{tabular} \\
\hline 150 & 1 & 10 & 1.1 & 1 & 90 & 1.9 & 2 & \begin{tabular}{l|l}
65 & 2.6
\end{tabular} \\
\hline 200 & 1 & 50 & 1.5 & 2 & 10 & 2.1 & 2 & \begin{tabular}{l|l}
90 & 2.9
\end{tabular} \\
\hline
\end{tabular}

Table11 MRC.11, $M_{40}$ CONCRETE COLUMN CIRCULAR SECTION FOR 28 DAYS

\begin{tabular}{|c|c|c|c|c|c|c|c|c|c|}
\hline \multirow{2}{*}{ LOAD (KV) } & \multicolumn{3}{|c|}{$\begin{array}{c}\text { TOP } \\
\text { Deflection in mm }\end{array}$} & \multicolumn{3}{c|}{$\begin{array}{c}\text { MIDDLE } \\
\text { Deflection in mm }\end{array}$} & \multicolumn{3}{c|}{$\begin{array}{c}\text { BOTTOM } \\
\text { Deflection in mm }\end{array}$} \\
\cline { 2 - 11 } & Inner & Outer & F.R & Inner & Outer & F.R & Inner & Outer & F.R \\
\hline 50 & 0 & 0 & 0 & 0 & 0 & 0 & 0 & 0 & 0 \\
\hline 100 & 0 & 20 & 0.2 & 0 & 40 & 0.4 & 0 & 40 & 0.4 \\
\hline 150 & 0 & 90 & 0.9 & 0 & 75 & 0.75 & 1 & 10 & 1.1 \\
\hline 200 & 1 & 25 & 1.25 & 1 & 20 & 1.2 & 1 & 75 & 1.75 \\
\hline 250 & 1 & 75 & 1.75 & 1 & 40 & 1.4 & 3 & 00 & 3.0 \\
\hline 300 & 1 & 20 & 1.2 & 2 & 10 & 2.1 & 4 & 40 & 4.4 \\
\hline
\end{tabular}

Table 12. MRC.22. $M_{40}$ CONCRETE COLUMN CIRCULAR SECTION I FOR 28 DAYS

\begin{tabular}{|c|c|c|c|c|c|c|c|c|c|}
\hline \multirow[t]{2}{*}{$\mathrm{LOAD}(\mathrm{KI})$} & \multicolumn{3}{|c|}{$\begin{array}{c}\text { TOP } \\
\text { Deflection in mm }\end{array}$} & \multicolumn{3}{|c|}{$\begin{array}{c}\text { IIDDLE } \\
\text { Deflection in mm }\end{array}$} & \multicolumn{3}{|c|}{$\begin{array}{c}\text { BOTTOMI } \\
\text { Deflection in mm }\end{array}$} \\
\hline & Imer' & Outel' & ER & Inmer! & Outer' & E.R & Inmer' & & FR \\
\hline 50 & 0 & 0 & 0 & 0 & 0 & 0 & 0 & 0 & 0 \\
\hline 100 & 0 & 20 & 0.2 & 0 & 10 & 0.1 & 0 & 40 & 0.4 \\
\hline 150 & 0 & 90 & 0.9 & 0 & 75 & 0.75 & 1 & 10 & 1.1 \\
\hline 200 & 0 & 25 & 0.25 & 1 & 20 & 1.2 & 1 & 75 & 1.75 \\
\hline 250 & 0 & 75 & 0.75 & 2 & 40 & 2.4 & 2 & 00 & 2.00 \\
\hline 300 & 1 & 20 & 1.2 & 1 & 10 & 1.1 & 3 & 40 & 3.4 \\
\hline
\end{tabular}

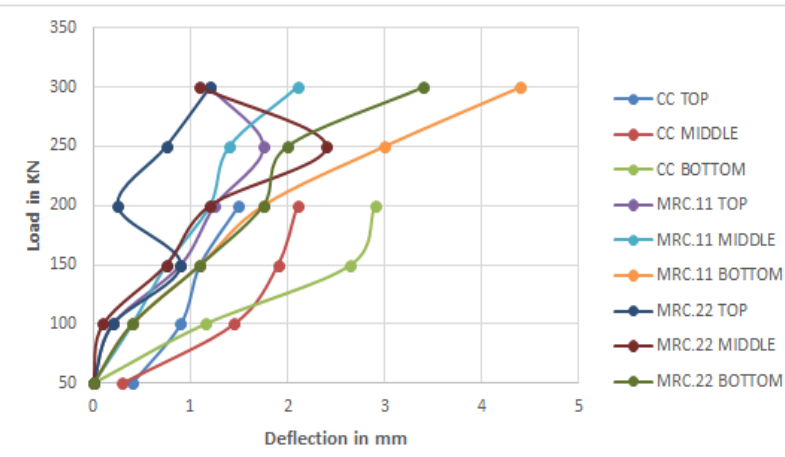

Fig 7. $M_{40}$ Grade Concrete Circular section

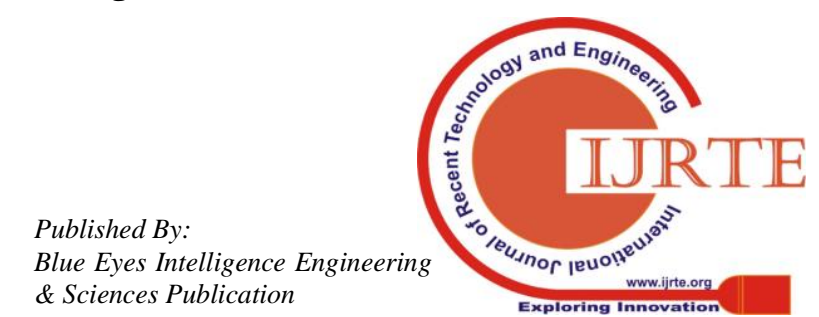




\section{Experimental Behavior of Composite Infilled \& Encased Column by using MSAND, Metakaolin \& Recron}

Fibre

\subsection{Catastrophe Approaches:}

The failure mechanism of short composite columns based upon the yielding of steel and crushing strength of concrete. The load is the axial direction in the column is stronger; the plane of bending and the slenderness for buckling of that plane is less than for minor axis buckling. Stiffness along the whole length of the column differs owing to an uncracked concrete member at the ends with a growing rate of cracking nearer the bottom to the center. Stiffeners play an important role for overall buckling of the columns if suppose stiffener stiffnesses were less, the buckling of longitudinal stiffeners were prevented by the concrete. These types of failure the local buckling occurred before reaching ultimate load. It was identified in the composite column initial state buckling occurs in one of the plates before reaching the ultimate load, and the other plate tends to buckle once reach the maximum load.

Table 13. CC $3 \mathrm{M}_{40}$ CONCRETE COLUMN SQUARE SECTION FOR 28 DAYS

\begin{tabular}{|c|c|c|c|}
\hline LOAD KN & \multicolumn{3}{|c|}{ DEFLECTION IN (mm) } \\
\cline { 2 - 4 } & TOP & IIIDDLE & B0TT0M \\
\hline 50 & 0.40 & 0.90 & 1.50 \\
\hline 100 & 0.90 & 2.00 & 2.40 \\
\hline 150 & 1.10 & 2.90 & 3.30 \\
\hline 170 & 1.40 & 1.90 & 3.65 \\
\hline
\end{tabular}

Table 14 MRC.3, M $_{40}$ CONCRETE COLUMN SQUARE SECTION FOR 28 DAYS

\begin{tabular}{|c|c|c|c|}
\hline \multirow{2}{*}{ LOAD (KI) } & \multicolumn{3}{|c|}{ DEFLECTIONIN(mm) } \\
\cline { 2 - 4 } & TOP & IIIDDLE & BOTTOMI \\
\hline 50 & 0.40 & 0.60 & 0.90 \\
\hline 100 & 0.90 & 1.45 & 2.15 \\
\hline 150 & 1.30 & 1.90 & 2.65 \\
\hline 200 & 2.20 & 2.60 & 3.75 \\
\hline
\end{tabular}

Table 15. MRC.33. $M_{40}$ CONCRETE COLUMN SQUARE SECTION I FOR 28 DAYS

\begin{tabular}{|c|c|c|c|}
\hline \multirow{2}{*}{ LOAD (KN) } & \multicolumn{3}{|c|}{ DEFLECTION IN (mm) } \\
\cline { 2 - 4 } & TOP & IIIDDLE & BOTTOM \\
\hline 50 & 0.40 & 0.60 & 0.85 \\
\hline 100 & 0.90 & 1.45 & 2.15 \\
\hline 150 & 1.40 & 1.90 & 3.65 \\
\hline 200 & 2.00 & 2.40 & 4.20 \\
\hline 250 & 2.60 & 3.25 & 4.50 \\
\hline
\end{tabular}

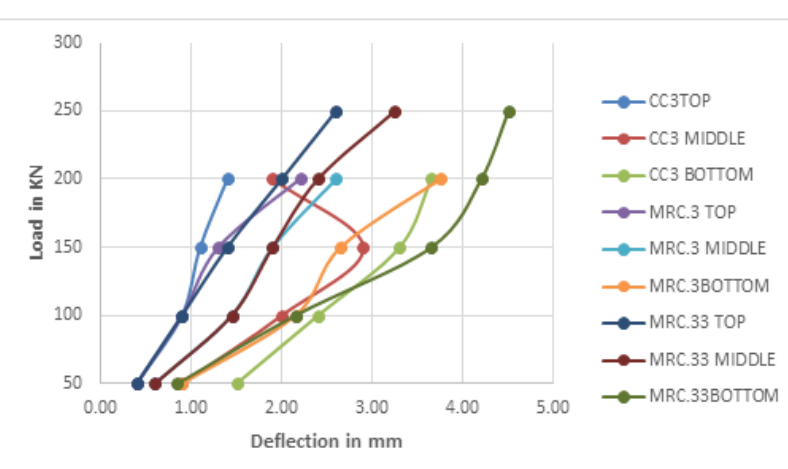

Fig.8. $M_{40}$ Grade Concrete Square section

\section{CONCLUSIONS}

From the experimental investigation and comparing $\mathrm{CC}$ and MRC led to the following observation and conclusion can be made on the basis of the experimental result

$>$ Concrete filled encased steel tubes have $1.0-1.8$ times higher than hollow tubes

The increase in compressive strength of infilled with encased steel tubes increases the load-carrying capacity by $10 \%$ for square concrete with encased sections and $15 \%$ for circular section concrete infilled sections

$>$ CFSTC- concrete infilled with encased steel tubes have $6 \%-15 \%$ higher strength than conventional concrete filled with encased steel tubes

$>$ Circular sections have a 10\% - 15\% higher load carrying compared to square sections

Load-carrying capacities of specimens are observed to increase by $15 \%-20 \%$ with a decrease in the height/thickness ratio

A laboratory investigation comparing $\mathrm{CC}$ and $\mathrm{MRC}$ led to the following. The maximum compressive strength of 30-45mpa was obtained for CC and in case the compressive strength of MRC1,2. It was 35-65 Mpa which shows compressive strength of MRC is more than $\mathrm{CC}$.

\section{REFERENCES}

1. PREN 1994 1-1: Design of composite steel and concrete structures. Part 1-1: General rules and rules for buildings. The final draft, 1 January 2002 European Committee for Standardization.

2. American Concrete Institute (ACI), Building code requirement for structural concrete (ACI 318-89) and commentary.

3. Load and resistance factor design method (AISC+LRFD)

4. British Standard BS 5400-Part 5

5. J.M. Portoles, M.R (2011). Experimental study of high strength concrete-filled circular tubular columns under eccentric loading. Journal of Constructional Steel Research, ELSEVIER, 623-633

6. ZhijingOu, B. C (2011) Experimental and Analytical Investigation of Concrete Filled Steel Tubular Columns. Journal of Structural Engineering, 137, 634-645

7. Qing Quan Liang, S.F. (2009). Nonlinear analysis of circular concrete-filled steel tubular short columns under axial loading. Journal of Constructional Steel Research, 2186-2196

8. Kenji Sakino, H.N (2004). The behaviour of Centrally Loaded Concrete-filled Steel tube short column. Journal of Structural Engineering, 180-188

9. Ben Young and Ehab Ellobody (2006), "Behavior of normal high strength concrete-filled compact steel tube circular stub columns", Journal of structural engineering, ASCE, Vol. No.62, pp 706-715

10. Ben Young and Ehab Ellobody (2006), "Experimental investigation of concrete-filled cold-formed high strength stainless steel tube columns", Journal of structural engineering, ASCE, Vol. No.62, pp 484-492 
11. M.a.Dabaon, M.H.El-Boghdadi and M.F.Hassanein (2009),'Experimental investigation on concrete-filled stainless steel stiffened tubular stub columns", Journal of constructional steel research, Vol.No.31, pp 300

12. M.R.Ganesamoorthy and Dr.S.Arivalagan (2017, "Experimental behavior of composite infilled column by using silicafume and metakoalin. International journal of civil engineering and technology (IJCIET), Vol.No.1, pp 203-208. ISSN No.0976:6316 